\title{
Fair Prices to Achieve a Living Income for Small Farmers and Its Relation to Local Food Purchase Programs
}

\author{
Ruud Bronkhorst \\ InfoBridge Foundation, Netherlands
}

Copyright $\mathrm{O} 2018$ by authors, all rights reserved. Authors agree that this article remains permanently open access under the terms of the Creative Commons Attribution License 4.0 International License

\begin{abstract}
Based on the Living Income concept, a methodology has been developed to calculate 'fair' prices for peasants for different crops. Application of this method can guide both policy makers and companies in their development of 'ethical' policies, based on the Universal Declaration of Human Rights. "Everyone who works has the right to just and favorable remuneration ensuring for himself and his family an existence worthy of human dignity..." An explanation of the living income / fair price methodology and a practical example of its application, is followed by arguments why market prices are not sufficient to combat poverty among peasants and why a paradigm shift from the use of prices decided by the market with all its imperfections, to an approach founded on ethics is needed. Particular attention is given to local food purchase programs.
\end{abstract}

Keywords Fair Price, Living Income, Living Wage, Ethics, Local Purchase, Sustainability, Fair Trade, SDG's

\section{Introduction}

The aim of this paper is to stimulate a discussion of how to raise the farmers' income in a non-conventional way, namely by providing another way of looking at prices. For poverty alleviation as well as for food security with the agricultural producers, it is necessary to take a different look at producer prices, especially for small farmers. As long as farmers don't earn a sufficient livelihood for themselves and their family, alternative ways than market prices have to be looked at. This paper provides an alternative application for market prices, the 'fair prices', and shows a way to calculate these fair prices.

After many years of progress, the absolute number of undernourished people in the world has actually increased in recent years, from 784 million in 2015 to 821 million in
2017. More than 2 billion people lack the micronutrients needed for growth, development and disease prevention [1].

More than 90 percent of the 570 million farms worldwide are managed by an individual or a family, relying predominately on family labor. 80 per cent of the food consumed in a large part of the developing world. Globally, 84 percent of family farms are smaller than 2 hectares and manage only 12 percent of all agricultural land. While small farms tend to have higher yields than larger farms, labor productivity is less and most small family farmers are poor and food-insecure. [2]

The sustainability and future food security of these farms may be threatened by intensive resource use. Public policies that recognize the diversity and complexity of the challenges faced by family farms throughout the value chain are necessary for ensuring food security [3].

Improving access to safe and nutritious food is fundamental to ensuring the prospects of future generations. Children who are properly nourished during the first 1,000 days of their lives are $33 \%$ more likely to escape poverty as adults. Yet, currently 151 million children under the age of 5 have experienced chronic malnutrition. This represents an immense loss of individual and economic potential [4].

The reason that people are undernourished often is that they just don't have the money to buy food. This fundamental human right to food security must be addressed by lifting people out of poverty.

"Economic growth is a key success factor for reducing undernourishment, but it has to be inclusive and provide opportunities for improving the livelihoods of the poor. Enhancing the productivity and incomes of smallholder family farmers is key to progress" [5].

Stiglitz gives in his book 'The Price of Inequality' a number of reasons why lack of possibilities are a hindrance not only to the people concerned, but also to society as a whole. Among his arguments are the facts that malnourished workers are less productive and that hunger 
and inadequate nutrition impede learning [6].

In 1996 the World Food Summit adopted the following definition of food security:

"Food security exists when all people, at all times, have physical and economic access to sufficient, safe and nutritious food that meets their dietary needs and food preferences for an active and healthy life". [7]

FAO defines Food Insecurity as: Food insecurity exists when people do not have adequate physical, social or economic access to food as defined above [8].

Although sufficient financial means does not necessarily imply that persons will make the right decisions when spending their money, sufficient income is the key for marginalized and deprived people to set their own priorities.

Yet, an ethical aspect in food production that until now has not received the attention it deserves, is the living condition of the small farmer. Food security in rural areas depends on supply and demand of food and ability to pay.

There is broad agreement that small farmers have a larger output/ha than large farms $[9,10]$. But these small farmers and their living conditions are not sufficiently taken into consideration by policy makers. Also in food programs such as in India and Brazil all attention is on the target-group, the poor consumer, with little attention to the poor producer.

When we talk about universal human rights, esp. article 23 and article 25 are relevant to the matters of living wages and -incomes and the corresponding fair prices.

In Article 23 of the 'Universal Declaration of Human Rights' is written:

"Everyone who works has the right to just and favorable remuneration ensuring for himself and his family an existence worthy of human dignity, and supplemented, if necessary, by other means of social protection."

And In Article 25,

"Everyone has the right to a standard of living adequate for the health and well-being of himself and of his family, including food, clothing, housing and medical care and necessary social services, and the right to security in the event of unemployment, sickness, disability, widowhood, old age or other lack of livelihood in circumstances beyond his control." [11]

These articles are at the basis of the SDGs, the Sustainable Development Goals, adopted in 2015 by the United Nations.

Goals 1 'No Poverty' and 2 'Zero Hunger' are about ending poverty and hunger, and achieving food security [12]

In industry, the living wage concept has been developed which implies that every worker has a right to a decent income, sufficient for him/her and his/her family.

In June 2008 an ILO Declaration on Social Justice was adopted by The International Labour Conference that supports "policies in regard to wages and earnings, hours and other conditions of work, designed to ensure a just share of the fruits of progress to all and a minimum living wage to all employed and in need of such protection" (my italics) [13].

In 2013 the following definition of a living wage has been agreed to by the Global Living Wage Coalition, consisting of Fairtrade International, Forest Stewardship Council (FSC), GoodWeave, Sustainable Agriculture Network/Rainforest Alliance (SAN/RA), Social Accountability International (SAI) and UTZ Certified.

"A living wage is the remuneration received for a standard work week by a worker in a particular place sufficient to afford a decent standard of living for the worker and her or his family. Elements of a decent standard of living include food, water, housing, education, health care, transport, clothing, and other essential needs including provision for unexpected events. " [14]

In agriculture, a similar concept has been developed, the living income. When a farmer works full-time, he or she should be able to earn such a living income. A Definition for Living Income proposed during a Practitioners' Workshop hosted by ISEAL and GIZ February $2 \& 3,2015$, Eschborn, is:

"A living income is the net income of a household earned/generated under conditions of decent work, sufficient to enable all members of the (average) household to afford a decent standard of living", whereby

- $\quad$ Net income $=$ Total income minus all costs

- Household is a group of people (often family) who form an economic unit (pooling income and other livelihood assets), often (but not always) living under the same roof or within the same compound.

- ILO: Decent work sums up the aspirations of people in their working lives. It involves opportunities for work that is productive and delivers a fair income, security in the workplace and social protection for families, better prospects for personal development and social integration, freedom for people to express their concerns, organize and participate in the decisions that affect their lives and equality of opportunity and treatment for all women and men [15]

- FAO defines decent employment as work that provides a living income and reasonable working conditions. Work should be remunerative and dignified. It should enable people - whether through self-employment or wage labor - to provide for themselves and their families. Workers should be able to perform their work under safe and healthy conditions and have a voice in the work place [16].

In order to achieve this, the price the producer receives 
for his/her products should be such that the revenue is sufficient to allow a decent life for him/herself and all those working for him/her.

The solution of the international fair trade movement to fair prices is prices consisting of a price floor combined with a premium [17]. This approach does not define fair prices on the basis of time spent and productivity levels however, whereas the living income/ fair price methodology has been developed to calculate a so-called 'fair' price for each crop on the basis of the methods of production that are most common in the region concerned. This to enable the farmer to earn a living income, as well as to have financial resources for sustainable investments.

This fair price is the minimum price the farmer should receive in order to attain a living income and food security. The living income / fair price methodology takes as its point of departure the real local costs of living and the real production costs, and thus leads to different fair prices in different places.

\section{Methodology}

The methodology consists of the development of a theoretical model that is then applied to a real case. Starting from the definition of Living Wages as the minimum amount wage-earners should earn, a concept of Living Income for the peasant is developed. While the living wage concept refers to the individual, the living income concept refers to the household. The living income concept for the farmer's household takes into account the same basic needs for the farmer as for the wage-earner (a decent standard of living for the worker and her or his family, meaning sufficient and good quality food, water, housing, education, health care, transport, clothing, and other essential needs, including provision for unexpected events). For fair price calculations an additional amount is added for investments in agricultural tools. To calculate a living income for a farmer we take the living wage multiplied by the number of family workers plus all investment and other costs (incl. depreciation). In the costs are also included the wages of casual labor at living wage prices. To this an additional percentage is added to enable investments to improve future yields ${ }^{1}$. In order to achieve this income on a given surface, taking into consideration weather-related conditions, the crops that can be grown, and other circumstances influencing both yields and production costs, the crops must have a certain sales price.

This price that the producer should receive in order to attain a living income, is called the 'fair' price. This price is based on the assumption of full-employment on the

\footnotetext{
${ }^{1}$ Note that this addition is not part of the definition of living income by ISEAL and GIZ
}

specific crop. In case the number of working hours is not reached over a year, we call the price the farmer has to receive in order to obtain a living income, the 'survival price'.

'Fair' means here that any price below this fair price is not sufficient, so this is the absolute minimum price the producer must receive. The methodology for calculating such 'fair' prices has been applied to food crops in Burkina Faso, in the Boucle du Mouhoun (maize, sorghum and millet), and then compared to market prices.

\section{Steps to be taken to Calculate Fair Prices}

- $\quad$ First of all Living Wages must be calculated.

- This means that the average family size must be known: adults, children below 15 , children $15-$ 18 years and people above the age of 60 .

- The total expenses of the household during the year, both on food and on non-food products.

- To this an approximate $10 \%$ must be added for additional and often unforeseen, expenses

- $\quad$ Average number of adult earners per household must be known

- $\quad$ Number of working-days per year = calendar days - Sundays - festivals - social obligations calamities - sick days

From this the Living Wage per adult earning family member per working day can be calculated.

- On basis of this Living Income (LI) can be calculated. $\mathrm{LI} / \mathrm{yr}=($ Number of Adult earners * LW) $\mathrm{x}$ 1,1 , whereby 1,1 is an additional $10 \%$ for investment costs. This percentage can be adapted to the specific situation. So a higher percentage can be used to enable the farmer to make use of items like better seeds and better equipment. Also additional investments needed to change to a more sustainable way of production may necessitate a higher percentage.

- $\quad$ Average farm size must be defined. Which average farm size is chosen depends on the chosen target group: marginal farmers, small farmers and which part of these groups. The farm size must be such that all labor can be used, not only for the specific crop but for all income generating activities together.

- Then production costs must be known for all products, including investment costs and depreciation. Even for one single crop these costs may differ, depending on method of cultivation, e.g. with/without fertilizer and/or improved seeds. In the production costs are also included the payment of rent to a land-owner or sharecropping whereby part of the produce is taken by the land-owner. These amounts can be considerable. 
- Production per ha. must be known for each way of cultivation such as with/without fertilizer and/or improved seeds.

- Additional income must be known, both from agricultural as from non-agricultural sources.

On basis of this, Fair Prices needed to achieve Living Wages / Living Income can be calculated.

\section{Results}

Graph 1 shows the difference between the calculated fair prices for two different production methods for millet, and the market price in the Boucle du Mouhoun region in Burkina Faso, a region with a Sudano-Sahelian climate. This difference is calculated for two cases, one in which the farmer uses a tractor and seeds of a local variety, and another one in which a plough is used in combination with improved seeds. It appears that the combination of plough and improved seeds is in the present circumstances the most beneficial for the farmer: it is with this combination that the "fair price" is closest to the market price.

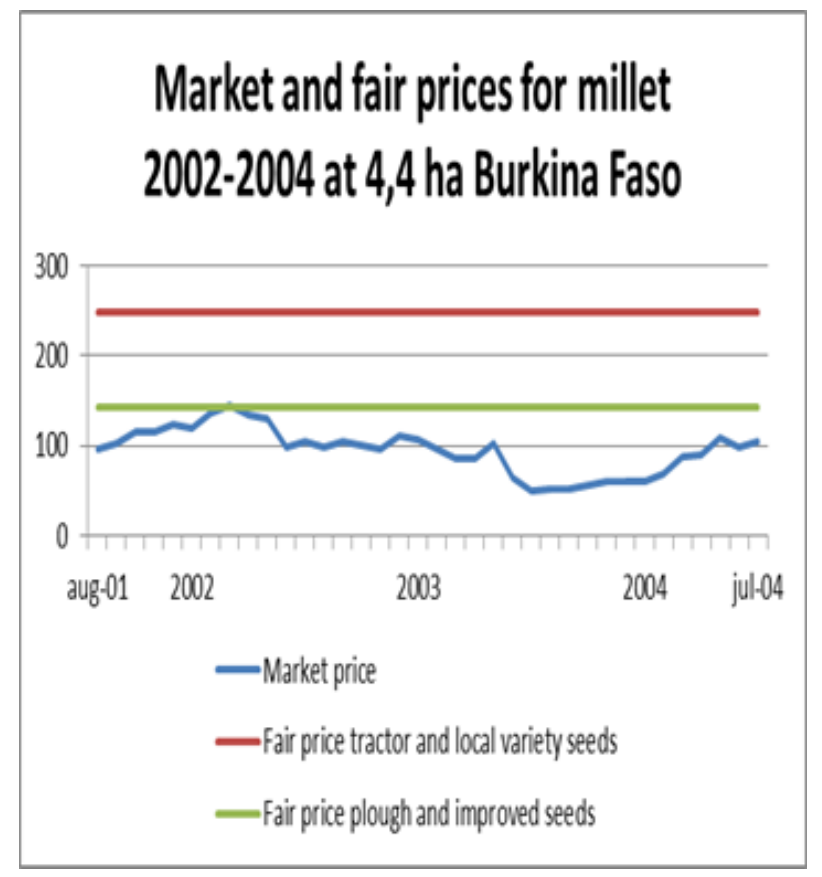

Source: adapted from [18]

Figure 1. Market and fair prices for millet at 4,4 ha in Burkina Faso

In this graph, calculated fair prices are given assuming that these remain stable for a period of some length. In reality this is not the case. Production costs differ from time to time due to changing prices for inputs, the season, climate change etc. Also living income changes from period to period, in the short term due to changes in food prices as well as in prices of non-food products, in the longer term also because of changing family compositions. So ideally both changes in cost of living and demographic changes must be recorded over time. Then you will get a fair price that also fluctuates over a longer period.

The reason why market prices should not be leading is that a market price is determined by supply and demand. A commonly made mistake is to call prices that are determined in this way, equilibrium prices. Equilibrium prices however only exist when there is a situation of perfect market conditions, a situation that rarely exists in reality.

In a model perfect competition is represented through supply and demand curves, which illustrate how a market reaches an equilibrium where supply for every product equals demand (figure 2). The corresponding price is the equilibrium price.

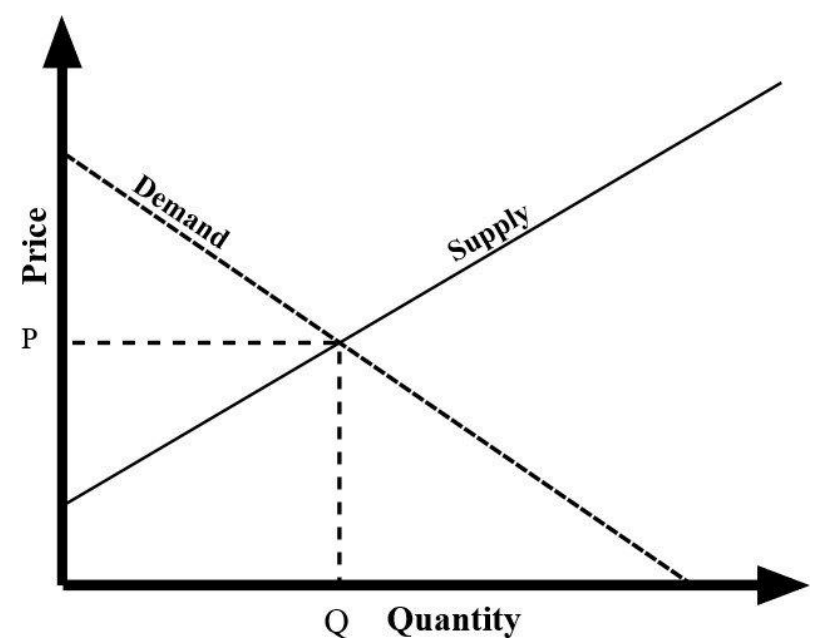

Figure 2. Model showing equilibrium price $\mathrm{P}$ corresponding with quantity Q

In reality however, market prices are not equilibrium prices since there is no perfect competition because of factors like the existence of monopsony (one single buyer) and oligopolies (few buyers). Monopsony and oligopolies have a great impact on the market and there is no perfect competition.

Besides countries often impose import and/or export restrictions, or subsidize certain products (think of the large agricultural subsidies in the US and the EU) that disturb markets in other countries.

Then there is also political interference by governments and by pressure groups on governments.

Besides there is the important point that the demand side consists of effective demand and not the demand based on needs, which means that the demand of people with no or little financial resources, is not taken into account. So it is important to realize that the demand of the poorest is not taken into account in the equilibrium price. This is the case for all products, but this is especially important for food products, as these are essential for survival.

Calculated fair prices can be used by governments as a guideline to decide whether there is a need to intervene in the food market. In the case of food assistance for instance, the effects of food aid on prices at the local markets should also be examined more in detail. Where local purchases are 
made for the provision of food aid, this fair price can guide the calculation of the prices that should be paid to producers in order to produce optimal positive development effects on the region that food is sourced from.

Fair prices can sometimes be achieved without major effort. For example, in Europe, consumer prices for a number of products can be raised when production is destined at a niche in the market. People are willing to pay more for an exclusive product. How much more they are willing to pay, depends on the income elasticity of their demand $^{2}$.

Besides costs, and that way prices too, can be lowered by more cooperation in the fields of transport, both national and international, and storage. This may take the form of e.g. common warehouses, common use of a container to ship goods and the mutual use of the same exporter.

In the majority of cases however, consumers have to pay more. What can be done to ease their pain and prevent them paying the full price for the income rise of the producers?

- Subsidies on food. An example of government subsidies is India, where there are food stores for the poor. A negative aspect of this is that the system is very vulnerable to fraud.

- Cash transfers. Cash transfers have many advantages over price subsidies. It is better targeted and therefore less expensive than a generalized price subsidy. It also avoids the introduction of price distortions.

- Security and intervention stocks. Food is stored to be used in cases of shortage and/or to regulate the market. A disadvantage is that this is capital that cannot be used for other ends, and is subject to loss in quality and quantity (rodents)

- Exporting less food, leaving more food to the local population

- In case of food aid: analysis of its direct and indirect consequences on the local market

- Subsidies on agricultural inputs such as seeds and equipment, for small farmers

- Analysis of the chain: are there excess profits or other problems in the chain? If so, action to tackle these imbalances

In order to apply fair prices, agreement of stakeholders is necessary. This will necessarily lead to a series of negotiations between stakeholders. How can companies that buy products from more countries and regions and need standard prices for consumers, deal with the problem

\footnotetext{
${ }^{2}$ In economics, income elasticity of demand measures the responsiveness of the quantity demanded for a good or service to a change in the income of the people demanding the good (Wikipedia)
}

of fair prices? Companies not only have to take into account producer prices, but also government rules and taxes (think of government regulations of cooperatives, anti-trust legislation and export- and other taxes).

This is a complex problem. This problem, which is faced by large companies and also by organizations like Fair Trade int. etc. is to be solved in practice.

Also, with regard to export products it is important that the company or organization takes into consideration that prices should be based on real, actual costs. This means that the basis upon which the consumer price is determined must not be the world market, but the reality in the field. Fair prices are different from region to region and that must be worked with: not a premium but actual costs. At a later stage the different producer prices in different countries can be averaged and this way the company or organization can arrive at a uniform sales price.

This may lead to a price that is too high so that the buyer does not pay a decent consumer price. In that case consultations with government and stakeholders about obstacles in the chain should be organized to analyze the problem. Consensus among all stakeholders in the chain is necessary to ensure that a Living Income is included in the producer price. Consensus is needed because it is difficult for an individual company to compete with other companies when paying a higher price than others. Therefore it is important that the local government sees the importance of the importance of such a price that the producer can achieve a living income and agrees to it, because the government can fix the rules. These stakeholders' meetings can be organized by the companies themselves and by the local government or NGO's.

When it appears impossible to arrive at consensus and the price cannot be calculated on the basis of the living income, stakeholders should reflect whether it would not be better for the farmer to change to other crops or other sources of income. It is a challenge for policy makers to find out what other possibilities for earning a decent income exist in the region. It is a difficult exercise, because if other possibilities exist in the region, many farmers would already have changed to other more rewarding work. The need to find alternatives is only more necessary in this case.

In 2006 both FAO and WFP argued that the local purchase at higher prices from local farmers is not beneficial because payment of a higher price leads to less food being available for the target group [19, 20].

Their opinion is that increased procurement costs would mean a transfer of WFP resources from the poorest of the poor to less poor farmers who produce a marketable surplus [19]. It should be realized, though, that the target groups in WFP programs such as 'school canteens' and 'vulnerable groups' such as mothers and sick people, are not chosen because of their individual poverty or through their families' lack of access to food, but because they belong to a special group, be it in a structural 
food-deficit area. Also in food-deficit areas there is a difference in food availability and the beneficiaries of the WFP programs are not by definition worse off than some producers in surplus areas.

The analysis of [19] and [20] assumes that a fixed amount is available for local purchase while the number of beneficiaries depends on the quantity of food that can be purchased. In reality however, the number of beneficiaries is fixed. Based on the number of beneficiaries to be fed, a quantity of food or an amount of funds to purchase food, is requested. If the amount pledged falls short, WFP should ask its donors to increase their monetary contribution.

The point of departure should not be "how much money is available and how many people can we feed for that amount', but 'on the basis of our analysis, we have concluded that a certain number of people are in need of being fed and to feed them we need that amount'. Then the responsibility is laid where it should be, namely with the donors. It is true that many donors are not keen to provide funds for local purchase, so lack of funds is a major problem. However, to conclude from this observation that the farmer must bear the consequences of this lack of funds, is putting things upside down [21].

Some years ago WFP has greatly improved the development effects of its local purchases by introducing its Purchase for Progress (P4P) programme. Through the Purchase for Progress (P4P) programme, WFP - which itself has pledged to source 10 percent of its food purchases from smallholder farmers - encourages national governments and the private sector to buy food in ways that benefit smallholders [22].

Unfortunately, market prices are still leading. Prices and quantities are negotiated directly with farmers' organizations, based upon market prices for similar quality products on the open market [23].

WFP also restricts the prices it pays for locally procured food to below import parity regardless of type of supplier, unless a donor has specifically requested procurement from smallholder farmers as the primary objective, agreeing to WFP paying a price above import parity [24].

For companies calculated fair prices can provide a guideline for paying minimum ethical prices. The OECD Guidelines for Multinational Enterprises, 2011 state that: "when multinational enterprises operate in developing countries, where comparable employers may not exist, (they should) provide the best possible wages, benefits and conditions of work, within the framework of government policies. These should be related to the economic position of the enterprise, but should be at least adequate to satisfy the basic needs of the workers and their families" [25].

Lately the concepts living wage and living income have attracted a lot of attention. Several companies and many NGO's make calculations for living wage and income in their region. The Living Income Community (a partnership between The Sustainable Food Lab, GIZ and the ISEAL Alliance) provides guidelines on methods for measuring and reporting information on current and living incomes, and for identifying and discussing strategies that will help actors take actions that can contribute to closing income gaps [26].

\section{Conclusions}

Producer prices are an important element in the fight against poverty and to attain food security at the level of small farmers. This subject deserves more attention from the academic community.

A paradigm shift from the use of prices decided by the market with all its imperfections, to an approach founded on ethics is needed. 'Ethical' here implies that any worker receives a decent income for full-time, sustainable work. So the market should no longer be seen as an objective factor, but should be corrected where necessary.

The developments at both company and NGO level concerning living wage and living income give rise to the hope that the fair price concept will also be further developed soon. It will be necessary to replace the payment of a 'premium' which still takes place, by a fair price which implies payment of an amount the producer is entitled to, instead of a gift by a benevolent donor. For a detailed description how to calculate fair prices according to the Living Income/ Fair Price methodology, see 'Guide How to Calculate Fair Prices' [27].

Fair prices are an important solution for the farmers' problems, but are not the only solution. The Living Income / Fair Price methodology can be used in combination with other approaches, such as sustainable agricultural practices like ecological agriculture or FAO's Commodity Chain Analysis $[28,29]$. Combined it will provide a boost for a decent life and food security for the farmer and her/his family and stimulate sustainable agricultural practices.

The effects on others, such as food consumers, should also be further studied. As conditions are different in each country, more research is needed to analyze the consequences of the payment of fair prices for several groups of the population and to advise local governments about adequate accompanying measures.

An abstract of this paper has been published in the proceedings of the XXVII European Society for Rural Sociology Congress in Krakow 2017 (http://www.ruralsociology.eu/wp-content/uploads/2017/0 9/Proceedings-ESRS-Krakow.pdf) (p.270). A French version of this abstract was published on the website ' $\mathrm{La}$ faim expliquée?' of November 2017 (http://lafaimexpliquee.org/La_faim_expliquee/Prix_equit able.html).

\section{Biography}

Ruud Bronkhorst (1948) is a Fair Price Expert associated with InfoBridge Foundation (IBF) (www.infobridge.org) in the Netherlands. He worked as staff member and as a 
consultant with several national and international organizations, such as FAO, WFP, Ministry of Foreign Affairs of the Netherlands and several NGO's. His publications include 'Guide How to Calculate Fair Prices', InfoBridge 2016, and 'How to strengthen the development effectiveness of local purchase for food aid', Development in Practice, 21:7, 913-929.

Mail: rbronkh@infobridge.org / rbronkh@planet.nl

\section{REFERENCES}

[1] https://www.worldbank.org/en/topic/food-security

[2] FAO. 2014. The State of Food and Agriculture 2014. Innovation in family farming. Rome FAO

[3] FAO, IFAD and WFP. 2015. The State of Food Insecurity in the World 2015. Meeting the 2015 international hunger targets: taking stock of uneven progress. Rome, FAO).

[4] https://www.worldbank.org/en/topic/food-security

[5] FAO, IFAD and WFP. 2015. The State of Food Insecurity in the World 2015. Meeting the 2015 international hunger targets: taking stock of uneven progress. Rome, FAO

[6] Stiglitz, Joseph E. 2013. The Price of Inequality, Penguin Books

[7] World Food Summit, 1996

[8] http://www.fao.org/docrep/005/y4671e/y4671e06.htm

[9] IFPRI (2007). The Future of Small Farms for Poverty Reduction and Growth, IFPRI 2020 Discussion Paper 42.

[10] FAO. 2014. The State of Food and Agriculture 2014. Innovation in family farming. Rome FAO.

[11] UN Human Rights http://www.un.org/en/universal-declara tion-human-rights/

[12] UN SDG's https://sustainabledevelopment.un.org/?menu= 1300

[13] https://www.ilo.org/wcmsp5/groups/public/---dgreports/ca binet/documents/genericdocument/wcms_371208.pdf

[14] Global Living Wage Coalition, 2013

[15] http://www.ilo.org/global/topics/decent-work/lang--en/ind ex.htm
[16] http://www.fao.org/rural-employment/background/en/

[17] FLO (Fairtrade Int.). www.fairtrade.net.

[18] Bronkhorst, Ruud (2013). 'Fair' Prices Peasants and the possibilities of a Living Income, InfoBridge, https://www.researchgate.net/publication/307882536 'Fair _Prices_Peasants_and_the_possibilities_of_a_Living_Inco me

[19] FAO (2006). 'The State of Food and Agriculture, Food Aid for Food Security?', FAO Agriculture Series No. 37, Rome: FAO (2006)

[20] WFP (2006). 'Food Procurement in Developing Countries'

[21] Bronkhorst, Ruud (2011). How to strengthen the development effectiveness of local purchase for food aid, Development in Practice, 21:7, 913-929

[22] http://www1.wfp.org/purchase-for-progress.

[23] https://www.wfp.org/purchase-progress/news/blog/smallho lder-friendly-food-procurement- $\% \mathrm{E} 2 \% 80 \% 93-\mathrm{p} 4 \mathrm{p} \% \mathrm{E} 2 \% 8$ $0 \% 99$ s-experience

[24] P4P Final Consolidated Procurement Report (September 2008 - December 2013) http://documents.wfp.org/stellent/ groups/public/documents/reports/wfp270609.pdf

[25] Hennis, Marjoleine and Nieuwenkamp, Roel. Scaling Up Living Wages in Global Supply Chains, OECD Working Paper 2016,

http://oecdinsights.org/2016/04/28/scaling-up-living-wages -in-global-supply-chains/

[26] Living Income Community https://www.living-income.co $\mathrm{m} /$

[27] Bronkhorst, Ruud (2016). Guide How to Calculate Fair Prices, InfoBridge.https://www.researchgate.net/publicatio n/310133756_Guide_How_To_Calculate_Fair_Prices

[28] FAO 2005. Commodity Chain Analysis; Impact Analysis Using Market Prices, Easypol Module 045, http://www.fao.org/docs/up/easypol/332/value_chain_anal ysis_market_prices_045en.pdf

[29] Bronkhorst, Ruud (2014). Towards an integrated approach for project analysis for small farmers: the Living Income / Fair Price method, InfoBridge. https://www.researchgate.n et/publication/307560414_Towards_an_integrated_approa ch_for_project_analysis_for_small_farmers_the_Living_In come_Fair_Price_method 